\title{
KAJIAN KINERJA JALAN TRANS KALIMANTAN HANDIL BAKTI KABUPATEN BARITO KUALA (STUDI KASUS RUAS JALAN TRANS KALIMANTAN HANDIL BAKTI DARI KM. 1 + 000 S.D. KM. 2 + 900)
}

${ }^{1}$ Muhammad Zaid

${ }^{2}$ Adhi Surya

${ }^{3}$ Hendra Cahyadi

${ }^{1}$ Mahasiswa Prodi (S-1) Teknik Sipil, Fakultas Teknik, Uniska MAB

${ }^{2,3}$ Dosen Prodi (S-1) Teknik Sipil, Fakultas Teknik, Uniska MAB

Jalan Adhyaksa No. 2, Banjarmasin, Kalimantan Selatan 70123

E-mail: muhammadzaidd077@gmail.com/HP.+6281253569789

\begin{abstract}
ABSTRAK
Jalan Trans Kalimantan adalah jalan poros yang menghubungkan Kota Banjarmasin dan Kabupaten Barito Kuala. Jalan Trans Kalimantan merupakan Jalan Nasional yang satu-satunya akses jalan yang menghubungkan Provinsi Kalimantan Selatan dan Kalimantan Tengah. Saat ini merupakan jalan satu-satunya yang digunakan oleh masyarakat Handil Bakti yang sering melakukan perjalanan menuju ke Kota Banjarmasin. Kawasan Handil Bakti merupakan kawasan pemukiman masyarakat yang berada di wilayah perbatasan Kota Banjarmasin dengan Kabupaten Barito Kuala. Memiliki pergerakan lalu lintas yang tinggi pada saat jam sibuk yaitu pagi dan sore hari. Oleh karena itu perlu diadakan analisis kinerja ruas jalan Trans Kalimantan dengan melakukan pengamatan pergerakan lalu lintas di pos 1 di depan toko buah dan pos 2 di depan SPBU Handil Bakti berjarak sekitar 2,9 km (KM. $1+000$ s.d. KM. 2 + 900) diantara pos 1 dan pos 2 selama 4 hari yaitu Sabtu, Minggu, Senin dan Selasa. Survei Traffic Counting (TC) dimulai dari pukul 08.00 sd 18.00 WITA untuk mendapatkan arus lalu lintas MC, LV dan HV. Selanjutnya melakukan perhitungan manual kapasitas jalan (C). Adapun analisis kapasitas jalan (C) ruas Trans Kalimantan dilakukan berdasarkan empat tahapan yaitu kapasitas dasar (Co), faktor penyesuaian akibat lebar jalur lalu lintas (Fcw), faktor penyesuaian akibat pemisah arah (FCsp), dan faktor penyesuaian akibat hambatan samping (FCsf). Langkah terakhir mendapatkan Volume/Capacity Rasio (V/C Rasio) atau Level of Service (LoS) atau Indeks Tingkat Pelayanan (ITP) menggunakan Tabel LoS dari Manual Kapasitas Jalan Indonesia (MKJI) Tahun 1997.
\end{abstract}

Kata Kunci : Volume Lalu Lintas (V), Kapasitas Jalan (C), Indeks Tingkat Pelayanan (ITP) dan Jalan Trans Kalimantan.

\section{ABSTRACT}

The Trans Kalimantan Road is a pivot road that connects Banjarmasin City and Barito Kuala Regency. The Trans Kalimantan Road is the National Road which is the only access road connecting the Provinces of South Kalimantan and Central 
Kalimantan. At present it is the only road used by the people of Handil Bakti who often travels to the city of Banjarmasin. The Handil Bakti area is a residential area located in the border area of Banjarmasin City and Barito Kuala Regency. Having a high traffic movement during rush hour ie morning and evening. Therefore it is necessary to conduct an analysis of the performance of the Trans Kalimantan road section by observing the movement of traffic at post 1 in front of the fruit shop and post 2 in front of the Handil Bakti gas station about $2.9 \mathrm{~km}$ (KM. $1+000$ to KM. $2+900$ ) between posts 1 and post 2 for 4 days, Saturday, Sunday, Monday and Tuesday. Traffic Counting Survey (TC) starts from 08:00 to 18:00 WITA to get the flow of $M C, L V$ and $H V$ traffic. Next do a manual calculation of road capacity $(C)$. The analysis of the road capacity $(C)$ of the Trans Kalimantan section is carried out based on four stages, namely basic capacity (Co), adjustment factor due to the width of the traffic lane $(F c w)$, adjustment factor due to separator direction (FCsp), and adjustment factor due to side barriers (FCsf). The final step is to get a Volume / Capacity Ratio (V / C Ratio) or Level of Service (LOS) or Service Level Index (ITP) using the LOS Table from the 1997 Indonesian Road Capacity Manual $(M K J I)$.

Keywords: Traffic Volume (V), Road Capacity (C), Service Level Index (ITP) and Trans Kalimantan Road.

\section{Latar Belakang}

\section{PENDAHULUAN}

Jalan Trans Kalimantan adalah jalan poros yang menghubungkan Kota Banjarmasin dan Kabupaten Barito Kuala. Jalan Trans Kalimantan merupakan Jalan Nasional yang satu-satunya akses jalan yang menghubungkan Provinsi Kalimantan Selatan dan Kalimantan Tengah. Saat ini Jalan Trans Kalimantan KM. $1+000$ s.d. KM. $2+900$ merupakan jalan satu-satunya Jalan yang digunakan oleh masyarakat Handil Bakti yang sering melakukan perjalanan menuju ke jalan $\mathrm{H}$. Hasan Basri Kota Banjarmasin, dan tingkat lalu lintas yang tinggi pada waktu waktu tertentu dikarenakan jalan tersebut adalah satu satunya dipegunakan masyakarat yang dari Marabahan maupun dari Banjarmasin dan warga sekitar jalan banyaknya komplek perumahan di Handil Bakti.

Mengingat pentingnya peran dan fungsi ruas jalan Trans Kalimantan maka diruas jalan ini perlu diadakan analisis kapasitas dan tingkat pelayanan jalan. Hasil analisis akan memberikan gambaran apakah ruas jalan ini masih memadai atau memerlukan peningkatan seperti pelebaran jalan atau perubahan rekayasa lalu lintas. Seiring dengan bertambahnya kepemilikan kendaraan, serta kemajuan dibidang industri barang dan jasa menyebabkan meningkatkan volume lalu lintas. Dengan bertambahnya pengguna jalan terutama pada jam-jam tertentu sehingga menuntut adanya peningkatan mengenai kapasitas jalan dan kuantitas jalan. Untuk itulah perlu diadakan penelitian mengenai kapasitas jalan yang ada, terutama di wilayah Kabupaten Barito Kuala Ruas Jalan Trans Kalimantan Handil Bakti (KM. $1+000$ s.d. KM. $2+900$ ). 


\section{Tujuan Penelitian}

1. Mengetahui volume lalu-lintas lintas ruas Jalan Trans Kalimantan Handil Bakti (KM. $1+000$ s.d. KM. $2+900)$.

2. Mengetahui tingkat pelayanan jalan untuk menentukan kinerja jalan Trans Kalimantan (KM. 1 + 000 s.d. KM. 2 + 900).

\section{TINJAUAN PUSTAKA}

Kendaraan yang ada dijalan raya terdiri dari beberapa jenis kendaraan, maka dalam hubungannya sangat berpengaruh dengan kapasitas.Pengaruh dari setiap jenis kendaraan dihitung dengan membandingkan terhadap pengaruh mobil penumpang yang dipakai sebagai satuan sehingga hal ini dikenal dengan satuan mobil penumpang (MKJI 1997).

Volume Lalu Lintas adalah banyaknya kendaraan yang melewati suatu titik atau garis tertentu pada suatu penampang melintang jalan. Data pencacahan lalu lintas adalah informasi yang diperlukan untuk fase perencanaan, desain, manajemen sampai pengoprasian jalan.Segmen jalan selama selang waktu tertentu yang dapat di ekspresikan dalam tahunan, harian (LHR), jam, dan subjam (MKJI 1997).

Menurut MKJI (1997) Kapasitas dapat didefinisikan sebagai arus maksimum yang dapat dipertahankan persatuan jam yang melewati suatu titik di jalan dalam kondisi yang ada. Nilai kapasitas telah diamati melalui pengumpulan data lapangan, oleh karena kurangnya lokasi yang arusnya yang mendekati kapasitas segmen jalan sendiri (sebagaimana ternyata dari kapasitas simpang sepanjang jalan), kapasitas juga telah diperkirakan secara teoritis dengan menganggap suatu hubungan matematik antara kerapatan, kecepatan, dan arus. Kapasitas dinyatakan dalam satuan mobil penumpang (smp), persamaan dasar untuk penentuan kapasitas adalah sebagai berikut:

$\mathrm{C}=\mathrm{Co} \times \mathrm{FCw} \times \mathrm{FCsp} \times \mathrm{FCsf}(\mathrm{smp} / \mathrm{jam})$

(Sumber : MKJI 1997, Hal.06-64)

Dimana :

$\mathrm{C}=$ Kapasitas

Co $\quad=$ Kapasitas dasar $(\mathrm{smp} / \mathrm{jam})$

$\mathrm{FCw} \quad=$ Faktor penyesuaian lebar jalur lalu-lintas

FCsp $\quad=$ Faktor penyesuaian pemisahan arah

FCsf $\quad=$ Faktor penyesuaian hambatan samping

\section{METODE PENELITIAN}

Metode yang digunakan dalam penelitian ini adalah metode deskriptif-kuantitatif yaitu analisis volume lalu lintas (V), kapasitas (C), densitas (V/C) dan tingkat pelayanan ruas jalan menggunakan MKJI 1997. Yang inputan dari data primer yaitu 
penelitian survei lalu-lintas dengan Traffic Counting (TC) di ruas Jalan Trans Kalimantan Handil Bakti (KM. $1+000$ s.d KM. $2+900$ ) sehingga dapat disimpulkan bahwa metode deskriptif kuantitatif adalah sebuah cara atau teknik yang dilakukan untuk memaparkan suatu permasalahan sehingga dapat dengan jelas dianalisis dan ditarik kesimpulan.

Ada pun langkah-langkah metode penelitian yang dilakukan sebagai berikut :

$>$ Pengambilan data primer :

1. Pengambilan data profil jalan Trans Kalimantan Handil Bakti (KM. $1+000$ s/d KM. 2 + 900) Kabupaten Barito Kuala dan situasi lingkungan.

2. Volume lalu-lintas dengan survei Traffic Counting dilaksanakan pada jam sibuk dan jam tidak sibuk lalu lintas dari pagi jam 08.00-18.00 wita dalam 4 hari yaitu 2 hari kerja sama 2 hari libur setiap pencatatan data dibagi dalam interval waktu selama 15 menit.

$>$ Pengambilan data sekunder diperoleh dengan cara meminta data pada badan atau instansi terkait. Data ini sifatnya memberikan gambaran umum daerah penelitian, seperti data geografis, peta jaringan jalan, dan informasi lain yang berhubungan dengan kelengkapan penelitian.

$>$ Untuk memproses data yang didapat dari data survey yang ada, dilakukan dengan menggunakan alat bantu berupa program Microsoft office terutama Word dan excel serta dilakukan pemilihan data untuk komposisi kendaraan yang menggunakan ruas-ruas jalan yang ditinjau menghasilkan volume lalulintas dan kapasitas dasar.

$>$ Hasil data yang telah diolah dikelompokan sesuai dengan jenis datanya masing-masing yang disajikan dalam bentuk kelompok terdiri dari komposisi kendaraan, persentasi kendaraan ringan, sedang dan berat. Selanjutnya, data diolah menjadi data arus lalu lintas per 15 menit untuk mendapatkan volume lalu-lintas dalam satuan smp/jam.

$>$ Lalu membandingkan volume lalu-lintas (V) per kapasitas jalan (C) untuk mendapatkan Density/Kepadatan (V/C).

$>$ Density/Kepadatan dilihat dalam Tabel Level Of Service (LoS) MKJI 1997 akan menafsirkan apakah Indeks Tingkat Pelayanan (ITP/LOS/Kinerja Jalan) dengan hurus A, B, C, D, E dan F (lihat Tabel 1).

Tabel 1. Level of Service (LOS) dengan Rasio Densitas (V/C)

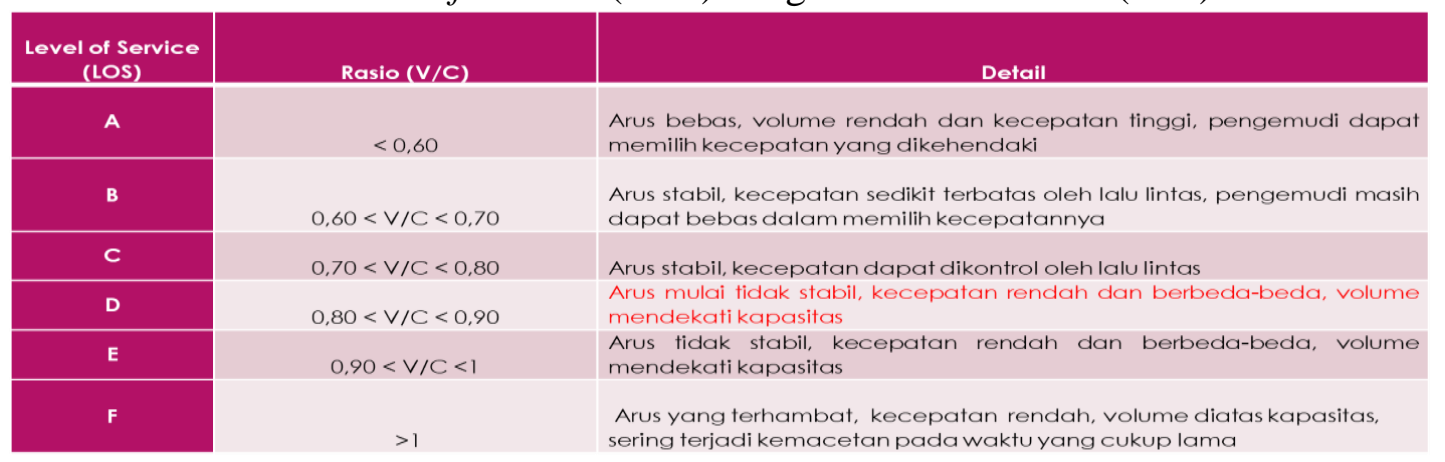

(Sumber : MKJI 1997) 
Tahapan penelitian tersebut sesuai dengan diagram alir pada Gambar 1.

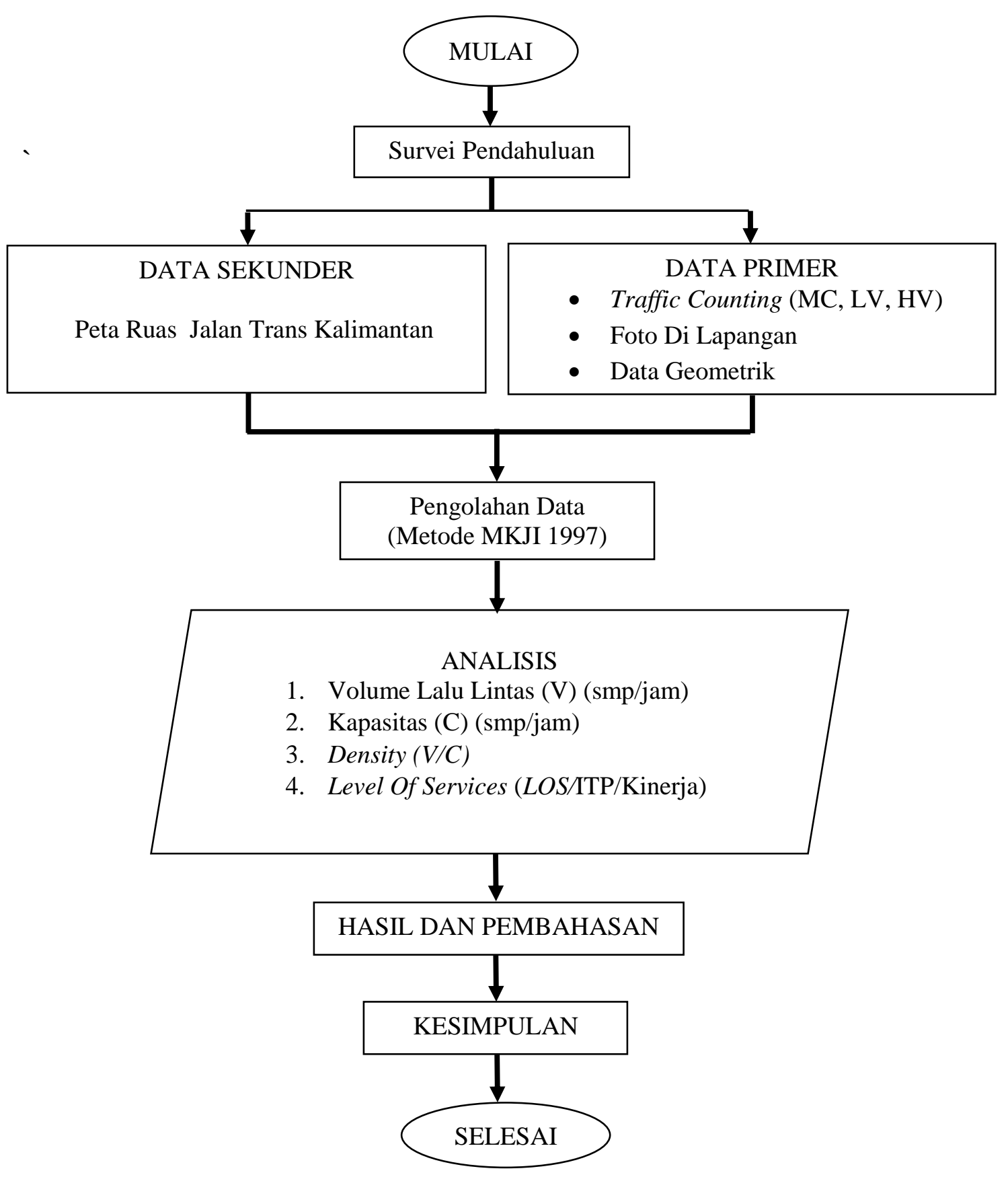

Gambar 1. Diagram Alir Penelitian

Sumber : Analisi, 2019 


\section{HASIL DAN PEMBAHASAN}

Untuk mendapatkan kinerja ruas jalan Trans Kalimantan Handil Bakti (KM. $1+$ 000 s.d. KM. 2 + 900) Kabupaten Barito Kuala. Dengan menggunakan metode MKJI 1997 yang mana tahapan awal melakukan TC (Traffic Counting) setelah dapat data tersebut dianalisi ke tahap berikutnya konversi EMP untuk mendapatkan volume "V" (SMP/JAM). Setelah itu menghitung kapasitas ruas jalan "C" (SMP/JAM) dalam hal ini Jalan Trans Kalimantan yang memiliki Dua Lajur Tanpa Median (2/2 D) dengan lebar efektif 7 meter. Selesai mendapatkan V/C (Densitas) maka dibandingkan maka akan mendapatkan angka rasio densitas lalu ditafsirkan oleh Tabel MKJI 1997 untuk Tingkat Pelayanan (Level of Service "LOS”).

\section{Traffic Counting (TC)}

Perhitungan data TC (kendaraan/15menit) dikonversikan dengan EMP sehingga menjadi Volume Lalu-lintas (smp/jam) dapat dilihat Tabel 2, Tabel 3, Tabel 4 dan Tabel 5.

Tabel 2. TC (kend/15menit)

\begin{tabular}{|c|c|c|c|c|c|c|c|c|c|c|c|c|}
\hline \multicolumn{13}{|l|}{ Sabtu,22 Juni 2019} \\
\hline \multirow{4}{*}{ WAKTU } & \multicolumn{6}{|c|}{ POS 1} & \multicolumn{6}{|c|}{ POS 2} \\
\hline & \multicolumn{2}{|c|}{ (LV) } & \multicolumn{2}{|c|}{$(\mathrm{HV})$} & \multicolumn{2}{|c|}{ (MC) } & \multicolumn{2}{|c|}{$(\mathrm{LV})$} & \multicolumn{2}{|c|}{ (HV) } & \multicolumn{2}{|c|}{ (MC) } \\
\hline & \multicolumn{2}{|c|}{$\operatorname{EMP}(1,0)$} & \multicolumn{2}{|c|}{$\operatorname{EMP}(1,3)$} & \multicolumn{2}{|c|}{$\operatorname{EMP}(0,40)$} & \multicolumn{2}{|c|}{$\operatorname{EMP}(1,0)$} & \multicolumn{2}{|c|}{$\operatorname{EMP}(1,3)$} & \multicolumn{2}{|c|}{$\operatorname{EMP}(0,40)$} \\
\hline & $\mathrm{kend} / \mathrm{jam}$ & $\mathrm{smp} / \mathrm{jam}$ & kend/jam & smp/jam & $\mathrm{kend} / \mathrm{jam}$ & smp/jam & $\mathrm{kend} / \mathrm{jam}$ & smp/jam & kend/jam & smp/jam & kend/jam & smp/jam \\
\hline $08.00-08.15$ & 219 & 219 & 2 & 2,6 & 757 & 302,8 & 260 & 260 & 0 & 0 & 444 & 177,6 \\
\hline $08.15-08.30$ & 275 & 275 & 2 & 2,6 & 711 & 284,4 & 188 & 188 & 4 & 5,2 & 666 & 266,4 \\
\hline $08.30-08.45$ & 213 & 213 & 1 & 1,3 & 710 & 284 & 201 & 201 & 1 & 1,3 & 737 & 294,8 \\
\hline $08.45-09.00$ & 137 & 137 & 3 & 3,9 & 578 & 231,2 & 130 & 130 & 3 & 3,9 & 408 & 163,2 \\
\hline $09.00-09.15$ & 232 & 232 & 2 & 2,6 & 695 & 278 & 210 & 210 & 2 & 2,6 & 446 & 178,4 \\
\hline $09.15-09.30$ & 221 & 221 & 4 & 5,2 & 651 & 260,4 & 188 & 188 & 2 & 2,6 & 576 & 230,4 \\
\hline $09.30-09.45$ & 166 & 166 & 4 & 5,2 & 676 & 270,4 & 196 & 196 & 5 & 6,5 & 727 & 290,8 \\
\hline $09.45-10.00$ & 156 & 156 & 5 & 6,5 & 621 & 248,4 & 157 & 157 & 1 & 1,3 & 410 & 164 \\
\hline $10.00-10.15$ & 174 & 174 & 7 & 9,1 & 635 & 254 & 181 & 181 & 8 & 10,4 & 458 & 183,2 \\
\hline $10.15-10.30$ & 143 & 143 & 7 & 9,1 & 698 & 279,2 & 169 & 169 & 8 & 10,4 & 576 & 230,4 \\
\hline $10.30-10.45$ & 151 & 151 & 7 & 9,1 & 656 & 262,4 & 196 & 196 & 6 & 7,8 & 725 & 290 \\
\hline $10.45-11.00$ & 133 & 133 & 7 & 9,1 & 653 & 261,2 & 144 & 144 & 7 & 9,1 & 429 & 171,6 \\
\hline $11.00-11.15$ & 115 & 115 & 7 & 9,1 & 778 & 311,2 & 137 & 137 & 5 & 6,5 & 608 & 243,2 \\
\hline $11.15-11.30$ & 134 & 134 & 9 & 11,7 & 839 & 335,6 & 148 & 148 & 9 & 11,7 & 545 & 218 \\
\hline $11.30-11.45$ & 153 & 153 & 10 & 13 & 699 & 279,6 & 99 & 99 & 4 & 5,2 & 593 & 237,2 \\
\hline $11.45-12.00$ & 119 & 119 & 5 & 6,5 & 700 & 280 & 122 & 122 & 9 & 11,7 & 358 & 143,2 \\
\hline $12.00-12.15$ & 99 & 99 & 6 & 7,8 & 781 & 312,4 & 91 & 91 & 5 & 6,5 & 401 & 160,4 \\
\hline $12.15-12.30$ & 134 & 134 & 8 & 10,4 & 800 & 320 & 107 & 107 & 6 & 7,8 & 445 & 178 \\
\hline $12.30-12.45$ & 102 & 102 & 5 & 6,5 & 727 & 290,8 & 99 & 99 & 5 & 6,5 & 605 & 242 \\
\hline $12.45-13.00$ & 107 & 107 & 8 & 10,4 & 711 & 284,4 & 90 & 90 & 10 & 13 & 361 & 144,4 \\
\hline $13.00-13.15$ & 98 & 98 & 5 & 6,5 & 661 & 264,4 & 71 & 71 & 9 & 11,7 & 397 & 158,8 \\
\hline $13.15-13.30$ & 118 & 118 & 4 & 5,2 & 725 & 290 & 82 & 82 & 5 & 6,5 & 445 & 178 \\
\hline $13.30-13.45$ & 107 & 107 & 6 & 7,8 & 528 & 211,2 & 74 & 74 & 6 & 7,8 & 498 & 199,2 \\
\hline $13.45-14.00$ & 116 & 116 & 5 & 6,5 & 617 & 246,8 & 61 & 61 & 7 & 9,1 & 382 & 152,8 \\
\hline $14.00-14.15$ & 111 & 111 & 8 & 10,4 & 692 & 276,8 & 79 & 79 & 6 & 7,8 & 306 & 122,4 \\
\hline $14.15-14.30$ & 124 & 124 & 7 & 9,1 & 694 & 277,6 & 79 & 79 & 6 & 7,8 & 437 & 174,8 \\
\hline $14.30-14.45$ & 113 & 113 & 8 & 10,4 & 827 & 330,8 & 79 & 79 & 7 & 9,1 & 341 & 136,4 \\
\hline $14.45-15.00$ & 115 & 115 & 8 & 10,4 & 673 & 269,2 & 62 & 62 & 8 & 10,4 & 367 & 146,8 \\
\hline $15.00-15.15$ & 111 & 111 & 6 & 7,8 & 717 & 286,8 & 85 & 85 & 4 & 5,2 & 312 & 124,8 \\
\hline $15.15-15.30$ & 118 & 118 & 9 & 11,7 & 712 & 284,8 & 80 & 80 & 7 & 9,1 & 351 & 140,4 \\
\hline $15.30-15.45$ & 89 & 89 & 8 & 10,4 & 814 & 325,6 & 102 & 102 & 9 & 11,7 & 377 & 150,8 \\
\hline $15.45-16.00$ & 119 & 119 & 3 & 3,9 & 753 & 301,2 & 85 & 85 & 3 & 3,9 & 381 & 152,4 \\
\hline $16.00-16.15$ & 89 & 89 & 5 & 6,5 & 917 & 366,8 & 67 & 67 & 5 & 6,5 & 486 & 194,4 \\
\hline $16.15-16.30$ & 87 & 87 & 6 & 7,8 & 708 & 283,2 & 83 & 83 & 6 & 7,8 & 365 & 146 \\
\hline $16.30-16.45$ & 120 & 120 & 3 & 3,9 & 802 & 320,8 & 71 & 71 & 2 & 2,6 & 482 & 192,8 \\
\hline $16.45-17.00$ & 105 & 105 & 3 & 3,9 & 733 & 293,2 & 69 & 69 & 4 & 5,2 & 366 & 146,4 \\
\hline $17.00-17.15$ & 105 & 105 & 5 & 6,5 & 817 & 326,8 & 54 & 54 & 4 & 5,2 & 495 & 198 \\
\hline $17.15-17.30$ & 122 & 122 & 3 & 3,9 & 708 & 283,2 & 53 & 53 & 4 & 5,2 & 408 & 163,2 \\
\hline $17.30-17.45$ & 108 & 108 & 4 & 5,2 & 802 & 320,8 & 61 & 61 & 4 & 5,2 & 531 & 212,4 \\
\hline $17.45-18.00$ & 121 & 121 & 4 & 5,2 & 712 & 284,8 & 66 & 66 & 4 & 5,2 & 697 & 278,8 \\
\hline Jumlah & 5379 & & 219 & & 28688 & & 4576 & & 210 & & 18942 & \\
\hline
\end{tabular}

(Sumber : Analisis, 2019) 
JURNAL KACAPURI

JURNAL KEILMUAN TEKNIK SIPIL

Volume 2 Nomor 2 Edisi Desember 2019

Tabel 3. TC (kend/15 menit)

\begin{tabular}{|c|c|c|c|c|c|c|c|c|c|c|c|c|}
\hline \multicolumn{13}{|l|}{ Minggu, 23 Juni 2019} \\
\hline \multirow{4}{*}{ WAKTU } & \multicolumn{6}{|c|}{ POS 1} & \multicolumn{6}{|c|}{ POS 2} \\
\hline & \multicolumn{2}{|c|}{ (LV) } & \multicolumn{2}{|c|}{ (HV) } & \multicolumn{2}{|c|}{$(\mathrm{MC})$} & \multicolumn{2}{|c|}{ (LV) } & \multicolumn{2}{|c|}{$(\mathrm{HV})$} & \multicolumn{2}{|c|}{$(\mathrm{MC})$} \\
\hline & \multicolumn{2}{|c|}{$\operatorname{EMP}(1,0)$} & \multicolumn{2}{|c|}{$\operatorname{EMP}(1,3)$} & \multicolumn{2}{|c|}{$\operatorname{EMP}(0,40)$} & \multicolumn{2}{|c|}{$\operatorname{EMP}(1,0)$} & \multicolumn{2}{|c|}{$\operatorname{EMP}(1,3)$} & \multicolumn{2}{|c|}{$\operatorname{EMP}(0,40)$} \\
\hline & kend/jam & smp/jam & kend/jam & smp/jam & kend/jam & smp/jam & kend/jam & smp/jam & $\mathrm{kend} / \mathrm{jam}$ & $\mathrm{smp} / \mathrm{jam}$ & kend/jam & smp/jam \\
\hline $08.00-08.15$ & 92 & 92 & 0 & 0 & 444 & 177,6 & 56 & 56 & 1 & 1,3 & 255 & 102 \\
\hline $08.15-08.30$ & 77 & 77 & 1 & 1,3 & 274 & 109,6 & 62 & 62 & 0 & 0 & 268 & 107,2 \\
\hline $08.30-08.45$ & 77 & 77 & 1 & 1,3 & 397 & 158,8 & 66 & 66 & 2 & 2,6 & 269 & 107,6 \\
\hline $08.45-09.00$ & 74 & 74 & 1 & 1,3 & 461 & 184,4 & 53 & 53 & 0 & 0 & 274 & 109,6 \\
\hline $09.00-09.15$ & 112 & 112 & 4 & 5,2 & 573 & 229,2 & 72 & 72 & 4 & 5,2 & 233 & 93,2 \\
\hline $09.15-09.30$ & 77 & 77 & 0 & 0 & 467 & 186,8 & 69 & 69 & 0 & 0 & 225 & 90 \\
\hline $09.30-09.45$ & 79 & 79 & 0 & 0 & 391 & 156,4 & 81 & 81 & 1 & 1,3 & 241 & 96,4 \\
\hline $09.45-10.00$ & 90 & 90 & 0 & 0 & 649 & 259,6 & 74 & 74 & 0 & 0 & 254 & 101,6 \\
\hline $10.00-10.15$ & 153 & 153 & 3 & 3,9 & 987 & 394,8 & 89 & 89 & 3 & 3,9 & 719 & 287,6 \\
\hline $10.15-10.30$ & 128 & 128 & 6 & 7,8 & 929 & 371,6 & 95 & 95 & 4 & 5,2 & 728 & 291,2 \\
\hline $10.30-10.45$ & 137 & 137 & 1 & 1,3 & 931 & 372,4 & 102 & 102 & 1 & 1,3 & 683 & 273,2 \\
\hline $10.45-11.00$ & 159 & 159 & 0 & 0 & 941 & 376,4 & 99 & 99 & 2 & 2,6 & 532 & 212,8 \\
\hline $11.00-11.15$ & 183 & 183 & 5 & 6,5 & 855 & 342 & 140 & 140 & 4 & 5,2 & 552 & 220,8 \\
\hline $11.15-11.30$ & 232 & 232 & 4 & 5,2 & 833 & 333,2 & 143 & 143 & 4 & 5,2 & 464 & 185,6 \\
\hline $11.30-11.45$ & 174 & 174 & 2 & 2,6 & 719 & 287,6 & 130 & 130 & 4 & 5,2 & 425 & 170 \\
\hline $11.45-12.00$ & 192 & 192 & 4 & 5,2 & 879 & 351,6 & 161 & 161 & 3 & 3,9 & 498 & 199,2 \\
\hline $12.00-12.15$ & 161 & 161 & 1 & 1,3 & 953 & 381,2 & 130 & 130 & 1 & 1,3 & 458 & 183,2 \\
\hline $12.15-12.30$ & 164 & 164 & 2 & 2,6 & 851 & 340,4 & 123 & 123 & 3 & 3,9 & 571 & 228,4 \\
\hline $12.30-12.45$ & 145 & 145 & 4 & 5,2 & 1021 & 408,4 & 120 & 120 & 3 & 3,9 & 485 & 194 \\
\hline $12.45-13.00$ & 141 & 141 & 4 & 5,2 & 1110 & 444 & 129 & 129 & 4 & 5,2 & 549 & 219,6 \\
\hline $13.00-13.15$ & 88 & 88 & 3 & 3,9 & 571 & 228,4 & 88 & 88 & 3 & 3,9 & 289 & 115,6 \\
\hline $13.15-13.30$ & 133 & 133 & 4 & 5,2 & 517 & 206,8 & 93 & 93 & 4 & 5,2 & 510 & 204 \\
\hline $13.30-13.45$ & 135 & 135 & 0 & 0 & 699 & 279,6 & 111 & 111 & 0 & 0 & 482 & 192,8 \\
\hline $13.45-14.00$ & 108 & 108 & 4 & 5,2 & 834 & 333,6 & 93 & 93 & 4 & 5,2 & 436 & 174,4 \\
\hline $14.00-14.15$ & 80 & 80 & 3 & 3,9 & 578 & 231,2 & 89 & 89 & 3 & 3,9 & 444 & 177,6 \\
\hline $14.15-14.30$ & 100 & 100 & 5 & 6,5 & 742 & 296,8 & 94 & 94 & 5 & 6,5 & 565 & 226 \\
\hline $14.30-14.45$ & 105 & 105 & 4 & 5,2 & 685 & 274 & 111 & 111 & 4 & 5,2 & 598 & 239,2 \\
\hline $14.45-15.00$ & 121 & 121 & 0 & 0 & 768 & 307,2 & 83 & 83 & 0 & 0 & 477 & 190,8 \\
\hline $15.00-15.15$ & 111 & 111 & 1 & 1,3 & 467 & 186,8 & 78 & 78 & 1 & 1,3 & 480 & 192 \\
\hline $15.15-15.30$ & 94 & 94 & 2 & 2,6 & 642 & 256,8 & 79 & 79 & 2 & 2,6 & 534 & 213,6 \\
\hline $15.30-15.45$ & 94 & 94 & 8 & 10,4 & 690 & 276 & 77 & 77 & 8 & 10,4 & 510 & 204 \\
\hline $15.45-16.00$ & 75 & 75 & 4 & 5,2 & 565 & 226 & 74 & 74 & 4 & 5,2 & 619 & 247,6 \\
\hline $16.00-16.15$ & 111 & 111 & 2 & 2,6 & 863 & 345,2 & 107 & 107 & 4 & 5,2 & 598 & 239,2 \\
\hline $16.15-16.30$ & 122 & 122 & 4 & 5,2 & 778 & 311,2 & 112 & 112 & 2 & 2,6 & 617 & 246,8 \\
\hline $16.30-16.45$ & 139 & 139 & 2 & 2,6 & 894 & 357,6 & 112 & 112 & 2 & 2,6 & 609 & 243,6 \\
\hline $16.45-17.00$ & 85 & 85 & 4 & 5,2 & 686 & 274,4 & 137 & 137 & 5 & 6,5 & 641 & 256,4 \\
\hline $17.00-17.15$ & 119 & 119 & 3 & 3,9 & 863 & 345,2 & 137 & 137 & 2 & 2,6 & 479 & 191,6 \\
\hline $17.15-17.30$ & 146 & 146 & 2 & 2,6 & 845 & 338 & 136 & 136 & 2 & 2,6 & 577 & 230,8 \\
\hline $17.30-17.45$ & 174 & 174 & 3 & 3,9 & 888 & 355,2 & 119 & 119 & 3 & 3,9 & 538 & 215,2 \\
\hline $17.45-18.00$ & 279 & 279 & 4 & 5,2 & 778 & 311,2 & 141 & 141 & 4 & 5,2 & 594 & 237,6 \\
\hline Jumlah & 5066 & & 105 & & 29018 & & 4065 & & 106 & & 19280 & \\
\hline
\end{tabular}

(Sumber : Analisis, 2019) 
JURNAL KACAPURI

JURNAL KEILMUAN TEKNIK SIPIL

Volume 2 Nomor 2 Edisi Desember 2019

Tabel 4. TC (kend/15 menit)

Senin, 24Juni 2019

\begin{tabular}{|c|c|c|c|c|c|c|c|c|c|c|c|c|}
\hline \multirow{4}{*}{ WAKTU } & \multicolumn{6}{|c|}{ POS 1} & \multicolumn{6}{|c|}{ POS 2} \\
\hline & \multicolumn{2}{|c|}{ (LV) } & \multicolumn{2}{|c|}{ (HV) } & \multicolumn{2}{|c|}{$(\mathrm{MC})$} & \multicolumn{2}{|c|}{ (LV) } & \multicolumn{2}{|c|}{ (HV) } & \multicolumn{2}{|c|}{ (MC) } \\
\hline & \multicolumn{2}{|c|}{$\operatorname{EMP}(1,0)$} & \multicolumn{2}{|c|}{$\operatorname{EMP}(1,3)$} & \multicolumn{2}{|c|}{$\operatorname{EMP}(0,40)$} & \multicolumn{2}{|c|}{$\operatorname{EMP}(1,0)$} & \multicolumn{2}{|c|}{$\operatorname{EMP}(1,3)$} & \multicolumn{2}{|c|}{$\operatorname{EMP}(0,40)$} \\
\hline & kend/jam & smp/jam & kend/jam & smp/jam & kend/jam & smp/jam & kend/jam & smp/jam & kend/jam & smp/jam & kend/jam & smp/jam \\
\hline $08.00-08.15$ & 182 & 182 & 4 & 5, & 1054 & 421,6 & 117 & 117 & 3 & 3,9 & 286 & 114,4 \\
\hline $08.15-08.30$ & 177 & 177 & 4 & 5, & 1156 & 462,4 & 89 & 89 & 3 & 3,9 & 280 & 112 \\
\hline $08.30-08.45$ & 188 & 188 & 3 & 3, & 1113 & 445,2 & 118 & 118 & 3 & 3,9 & 319 & 127,6 \\
\hline $08.45-09.00$ & 187 & 187 & 4 & 5, & 1086 & 434,4 & 84 & 84 & 3 & 3,9 & 337 & 134,8 \\
\hline $09.00-09.15$ & 204 & 204 & 5 & 6 & 1166 & 466,4 & 136 & 136 & 7 & 9,1 & 532 & 212,8 \\
\hline $09.15-09.30$ & 196 & 196 & 4 & 5, & 1147 & 458,8 & 110 & 110 & 10 & 13 & 488 & 195,2 \\
\hline $09.30-09.45$ & 204 & 204 & 6 & 7, & 1152 & 460,8 & 124 & 124 & 13 & 16,9 & 459 & 183,6 \\
\hline $09.45-10.00$ & 197 & 197 & 4 & 5, & 1052 & 420,8 & 98 & 98 & 11 & 14,3 & 456 & 182,4 \\
\hline $10.00-10.15$ & 165 & 165 & 4 & 5, & 693 & 277,2 & 118 & 118 & 11 & 14,3 & 405 & 162 \\
\hline $10.15-10.30$ & 162 & 162 & 5 & 6 & 661 & 264,4 & 89 & 89 & 7 & 9,1 & 280 & 112 \\
\hline $10.30-10.45$ & 145 & 145 & 5 & 6 & 764 & 305,6 & 123 & 123 & 8 & 10,4 & 366 & 146,4 \\
\hline $10.45-11.00$ & 140 & 140 & 4 & 5, & 722 & 288,8 & 90 & 90 & 5 & 6,5 & 456 & 182,4 \\
\hline $11.00-11.15$ & 89 & 89 & 4 & 5, & 847 & 338,8 & 119 & 119 & 19 & 24,7 & 417 & 166,8 \\
\hline $11.15-11.30$ & 71 & 71 & 4 & 5, & 739 & 295,6 & 91 & 91 & 19 & 24,7 & 478 & 191,2 \\
\hline $11.30-11.45$ & 88 & 88 & 6 & 7, & 824 & 329,6 & 121 & 121 & 15 & 19,5 & 401 & 160,4 \\
\hline $11.45-12.00$ & 102 & 102 & 4 & 5, & 767 & 306,8 & 90 & 90 & 13 & 16,9 & 475 & 190 \\
\hline $12.00-12.15$ & 68 & 68 & 4 & 5, & 846 & 338,4 & 114 & 114 & 15 & 19,5 & 428 & 171,2 \\
\hline $12.15-12.30$ & 73 & 73 & 4 & 5, & 660 & 264 & 99 & 99 & 16 & 20,8 & 568 & 227,2 \\
\hline $12.30-12.45$ & 62 & 62 & 4 & 5, & 766 & 306,4 & 121 & 121 & 8 & 10,4 & 512 & 204,8 \\
\hline $12.45-13.00$ & 66 & 66 & 4 & 5, & 850 & 340 & 92 & 92 & 11 & 14,3 & 491 & 196,4 \\
\hline $13.00-13.15$ & 68 & 68 & 2 & 2, & 746 & 298,4 & 77 & 77 & 15 & 19,5 & 565 & 226 \\
\hline $13.15-13.30$ & 69 & 69 & 2 & 2, & 582 & 232,8 & 65 & 65 & 9 & 11,7 & 601 & 240,4 \\
\hline $13.30-13.45$ & 70 & 70 & 3 & 3, & 608 & 243,2 & 85 & 85 & 8 & 10,4 & 619 & 247,6 \\
\hline $13.45-14.00$ & 76 & 76 & 5 & 6 & 685 & 274 & 62 & 62 & 4 & 5,2 & 560 & 224 \\
\hline $14.00-14.15$ & 91 & 91 & 4 & 5, & 679 & 271,6 & 107 & 107 & 5 & 6,5 & 710 & 284 \\
\hline $14.15-14.30$ & 89 & 89 & 2 & 2, & 696 & 278,4 & 130 & 130 & 6 & 7,8 & 605 & 242 \\
\hline $14.30-14.45$ & 80 & 80 & 4 & 5, & 670 & 268 & 87 & 87 & 3 & 3,9 & 641 & 256,4 \\
\hline $14.45-15.00$ & 82 & 82 & 2 & 2, & 728 & 291,2 & 82 & 82 & 2 & 2,6 & 508 & 203,2 \\
\hline $15.00-15.15$ & 100 & 100 & 5 & 6 & 499 & 199,6 & 83 & 83 & 13 & 16,9 & 627 & 250,8 \\
\hline $15.15-15.30$ & 86 & 86 & 4 & 5, & 574 & 229,6 & 94 & 94 & 14 & 18,2 & 618 & 247,2 \\
\hline $15.30-15.45$ & 90 & 90 & 4 & 5, & 653 & 261,2 & 106 & 106 & 7 & 9,1 & 575 & 230 \\
\hline $15.45-16.00$ & 98 & 98 & 2 & 2, & 638 & 255,2 & 90 & 90 & 12 & 15,6 & 544 & 217,6 \\
\hline $16.00-16.15$ & 116 & 116 & 4 & 5, & 1145 & 458 & 117 & 117 & 11 & 14,3 & 866 & 346,4 \\
\hline $16.15-16.30$ & 103 & 103 & 3 & 3, & 1367 & 546,8 & 125 & 125 & 8 & 10,4 & 821 & 328,4 \\
\hline $16.30-16.45$ & 113 & 113 & 2 & 2, & 1248 & 499,2 & 96 & 96 & 8 & 10,4 & 753 & 301,2 \\
\hline $16.45-17.00$ & 111 & 111 & 2 & 2, & 1261 & 504,4 & 66 & 66 & 5 & 6,5 & 762 & 304,8 \\
\hline $17.00-17.15$ & 161 & 161 & 3 & 3, & 1335 & 534 & 93 & 93 & 10 & 13 & 754 & 301,6 \\
\hline $17.15-17.30$ & 163 & 163 & 1 & 1, & 1413 & 565,2 & 96 & 96 & 12 & 15,6 & 855 & 342 \\
\hline $17.30-17.45$ & 167 & 167 & 3 & 3, & 1447 & 578,8 & 116 & 116 & 7 & 9,1 & 820 & 328 \\
\hline $17.45-18.00$ & 123 & 123 & 0 & 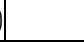 & 1456 & 582,4 & 95 & 95 & 6 & 7,8 & 773 & 309,2 \\
\hline Jumlah & 4822 & & 143 & & 36495 & & 4015 & & 365 & & 22011 & \\
\hline
\end{tabular}

(Sumber : Analisis, 2019) 
JURNAL KACAPURI

JURNAL KEILMUAN TEKNIK SIPIL

Volume 2 Nomor 2 Edisi Desember 2019

Tabel 5. TC (kend/15 menit)

Selasa, 25 Juni 2019

\begin{tabular}{|c|c|c|c|c|c|c|c|c|c|c|c|c|}
\hline \multirow{4}{*}{ WAKTU } & \multicolumn{6}{|c|}{ POS 1} & \multicolumn{6}{|c|}{ POS 2} \\
\hline & \multicolumn{2}{|c|}{ (LV) } & \multicolumn{2}{|c|}{ (HV) } & \multicolumn{2}{|c|}{$(\mathrm{MC})$} & \multicolumn{2}{|c|}{ (LV) } & \multicolumn{2}{|c|}{ (HV) } & \multicolumn{2}{|c|}{ (MC) } \\
\hline & \multicolumn{2}{|c|}{$\operatorname{EMP}(1,0)$} & \multicolumn{2}{|c|}{$\operatorname{EMP}(1,3)$} & \multicolumn{2}{|c|}{$\operatorname{EMP}(0,40)$} & \multicolumn{2}{|c|}{$\operatorname{EMP}(1,0)$} & \multicolumn{2}{|c|}{$\operatorname{EMP}(1,3)$} & \multicolumn{2}{|c|}{$\operatorname{EMP}(0,40)$} \\
\hline & kend/jam & smp/jam & kend/jam & smp/jam & kend/jam & smp/jam & kend/jam & smp/jam & kend/jam & smp/jam & kend/jam & smp/jam \\
\hline $08.00-08.15$ & 175 & 175 & 4 & 5, & 1110 & 444 & 176 & 176 & 2 & 2,6 & 1175 & 470 \\
\hline $08.15-08.30$ & 176 & 176 & 5 & 6 & 984 & 393,6 & 186 & 186 & 2 & 2,6 & 1203 & 481,2 \\
\hline $08.30-08.45$ & 187 & 187 & 3 & 3, & 1206 & 482,4 & 183 & 183 & 5 & 6,5 & 988 & 395,2 \\
\hline $08.45-09.00$ & 196 & 196 & 4 & 5, & 1109 & 443,6 & 189 & 189 & 6 & 7,8 & 1043 & 417,2 \\
\hline $09.00-09.15$ & 121 & 121 & 1 & 1, & 731 & 292,4 & 109 & 109 & 17 & 22,1 & 399 & 159,6 \\
\hline $09.15-09.30$ & 107 & 107 & 6 & 7, & 701 & 280,4 & 112 & 112 & 16 & 20,8 & 356 & 142,4 \\
\hline $09.30-09.45$ & 134 & 134 & 4 & 5, & 704 & 281,6 & 104 & 104 & 18 & 23,4 & 308 & 123,2 \\
\hline $09.45-10.00$ & 110 & 110 & 4 & 5, & 697 & 278,8 & 110 & 110 & 12 & 15,6 & 353 & 141,2 \\
\hline $10.00-10.15$ & 141 & 141 & 9 & 11, & 687 & 274,8 & 110 & 110 & 20 & 26 & 411 & 164,4 \\
\hline $10.15-10.30$ & 132 & 132 & 4 & 5, & 709 & 283,6 & 99 & 99 & 20 & 26 & 357 & 142,8 \\
\hline $10.30-10.45$ & 133 & 133 & 6 & 7, & 700 & 280 & 96 & 96 & 10 & 13 & 442 & 176,8 \\
\hline $10.45-11.00$ & 114 & 114 & 7 & 9, & 705 & 282 & 120 & 120 & 7 & 9,1 & 353 & 141,2 \\
\hline $11.00-11.15$ & 125 & 125 & 4 & 5, & 593 & 237,2 & 98 & 98 & 22 & 28,6 & 474 & 189,6 \\
\hline $11.15-11.30$ & 101 & 101 & 4 & 5, & 678 & 271,2 & 123 & 123 & 16 & 20,8 & 367 & 146,8 \\
\hline $11.30-11.45$ & 91 & 91 & 4 & 5, & 710 & 284 & 117 & 117 & 19 & 24,7 & 521 & 208,4 \\
\hline $11.45-12.00$ & 104 & 104 & 4 & 5, & 601 & 240,4 & 108 & 108 & 15 & 19,5 & 420 & 168 \\
\hline $12.00-12.15$ & 89 & 89 & 3 & 3, & 663 & 265,2 & 98 & 98 & 16 & 20,8 & 474 & 189,6 \\
\hline $12.15-12.30$ & 63 & 63 & 5 & 6 & 577 & 230,8 & 98 & 98 & 15 & 19,5 & 392 & 156,8 \\
\hline $12.30-12.45$ & 82 & 82 & 3 & 3, & 690 & 276 & 94 & 94 & 14 & 18,2 & 521 & 208,4 \\
\hline $12.45-13.00$ & 92 & 92 & 3 & 3, & 503 & 201,2 & 76 & 76 & 7 & 9,1 & 417 & 166,8 \\
\hline $13.00-13.15$ & 106 & 106 & 3 & 3, & 418 & 167,2 & 88 & 88 & 12 & 15,6 & 299 & 119,6 \\
\hline $13.15-13.30$ & 112 & 112 & 3 & 3, & 340 & 136 & 97 & 97 & 7 & 9,1 & 392 & 156,8 \\
\hline $13.30-13.45$ & 76 & 76 & 4 & 5, & 418 & 167,2 & 102 & 102 & 8 & 10,4 & 323 & 129,2 \\
\hline $13.45-14.00$ & 68 & 68 & 1 & 1, & 464 & 185,6 & 90 & 90 & 11 & 14,3 & 453 & 181,2 \\
\hline $14.00-14.15$ & 125 & 125 & 3 & 3, & 397 & 158,8 & 98 & 98 & 7 & 9,1 & 314 & 125,6 \\
\hline $14.15-14.30$ & 125 & 125 & 3 & 3, & 360 & 144 & 105 & 105 & 6 & 7,8 & 363 & 145,2 \\
\hline $14.30-14.45$ & 123 & 123 & 3 & 3, & 317 & 126,8 & 108 & 108 & 4 & 5,2 & 357 & 142,8 \\
\hline $14.45-15.00$ & 105 & 105 & 0 & 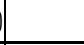 & 364 & 145,6 & 113 & 113 & 2 & 2,6 & 331 & 132,4 \\
\hline $15.00-15.15$ & 123 & 123 & 3 & 3, & 397 & 158,8 & 133 & 133 & 4 & 5,2 & 295 & 118 \\
\hline $15.15-15.30$ & 125 & 125 & 1 & 1, & 439 & 175,6 & 141 & 141 & 4 & 5,2 & 316 & 126,4 \\
\hline $15.30-15.45$ & 121 & 121 & 2 & 2, & 367 & 146,8 & 116 & 116 & 4 & 5,2 & 350 & 140 \\
\hline $15.45-16.00$ & 117 & 117 & 3 & 3, & 336 & 134,4 & 119 & 119 & 4 & 5,2 & 321 & 128,4 \\
\hline $16.00-16.15$ & 157 & 157 & 4 & 5, & 809 & 323,6 & 102 & 102 & 14 & 18,2 & 363 & 145,2 \\
\hline $16.15-16.30$ & 164 & 164 & 3 & 3, & 900 & 360 & 94 & 94 & 11 & 14,3 & 460 & 184 \\
\hline $16.30-16.45$ & 143 & 143 & 2 & 2, & 741 & 296,4 & 96 & 96 & 11 & 14,3 & 388 & 155,2 \\
\hline $16.45-17.00$ & 190 & 190 & 2 & 2, & 1015 & 406 & 110 & 110 & 8 & 10,4 & 383 & 153,2 \\
\hline $17.00-17.15$ & 147 & 147 & 1 & 1, & 1442 & 576,8 & 103 & 103 & 17 & 22,1 & 431 & 172,4 \\
\hline $17.15-17.30$ & 138 & 138 & 2 & 2, & 1278 & 511,2 & 84 & 84 & 10 & 13 & 470 & 188 \\
\hline $17.30-17.45$ & 163 & 163 & 4 & 5, & 1413 & 565,2 & 98 & 98 & 11 & 14,3 & 388 & 155,2 \\
\hline $17.45-18.00$ & 159 & 159 & 3 & 3, & 1518 & 607,2 & 103 & 103 & 13 & 16,9 & 486 & 194,4 \\
\hline Jumlah & 5060 & & 137 & & 28791 & & 4506 & & 427 & & 18457 & \\
\hline
\end{tabular}

(Sumber : Analisis, 2019) 
Volume Lalu-lintas (V)

Untuk hasil pengamatan Volume Lalu-lintas (V) dapat dilihat Tabel 6 dan Tabel 7.

Tabel 6. Volume Lalu-lintas (smp/jam) - Pos 1

\begin{tabular}{|c|c|r|r|c|}
\hline \multicolumn{5}{|c|}{ POS 1} \\
\hline \multirow{2}{*}{ Waktu Pengamatan } & \multicolumn{4}{|c|}{ Volume Lalu Lintas (smp/jam) } \\
\cline { 2 - 5 } & Sabtu & Minggu & \multicolumn{1}{c|}{ Senin } & Selasa \\
\hline $08.00-09.00$ & 1967,80 & 954,30 & 2517,10 & 2517,10 \\
\hline $09.00-10.00$ & 1834,20 & 1195,20 & 2631,20 & 1624,70 \\
\hline $10.00-11.00$ & 1766,90 & 2105,20 & 1771,40 & 1674,20 \\
\hline $11.00-12.00$ & 1844,10 & 2112,30 & 1644,20 & 1457,60 \\
\hline $12.00-13.00$ & 1742,30 & 2199,30 & 1538,60 & 1264,40 \\
\hline $13.00-14.00$ & 1508,00 & 1528,00 & 1347,00 & 1105,30 \\
\hline $14.00-15.00$ & 1672,40 & 1526,90 & 1462,90 & 1058,90 \\
\hline $15.00-16.00$ & 1674,90 & 1340,40 & 1339,10 & 1289,10 \\
\hline $16.00-17.00$ & 1698,50 & 1761,00 & 2465,70 & 2010,30 \\
\hline $17.00-18.00$ & 1705,20 & 2080,60 & 2883,50 & 2887,40 \\
\hline
\end{tabular}

(Sumber : Analisis, 2019)

Tabel 7. Volume Lalu-lintas (smp/jam) - Pos 2

\begin{tabular}{|c|c|r|r|c|}
\hline \multicolumn{5}{|c|}{ POS 2 } \\
\hline \multirow{2}{*}{ Waktu Pengamatan } & \multicolumn{4}{|c|}{ Volume Lalu Lintas (smp/jam) } \\
\cline { 2 - 5 } & \multicolumn{1}{|c|}{ Sabtu } & \multicolumn{1}{c|}{ Minggu } & \multicolumn{1}{c|}{ Senin } & Selasa \\
\hline $08.00-09.00$ & 1691,40 & 667,30 & 912,40 & 2517,10 \\
\hline $09.00-10.00$ & 1627,60 & 683,70 & 1301,80 & 1083,30 \\
\hline $10.00-11.00$ & 1707,30 & 1464,40 & 1063,10 & 1124,30 \\
\hline $11.00-12.00$ & 1538,70 & 1366,50 & 1215,20 & 1252,40 \\
\hline $12.00-13.00$ & 1137,50 & 1469,50 & 1290,60 & 1155,20 \\
\hline $13.00-14.00$ & 1116,40 & 1085,80 & 1273,80 & 1013,20 \\
\hline $14.00-15.00$ & 926,80 & 1072,70 & 1412,40 & 994,70 \\
\hline $15.00-16.00$ & 876,90 & 1326,30 & 1371,60 & 1042,60 \\
\hline $16.00-17.00$ & 1039,20 & 1470,90 & 1668,50 & 1102,00 \\
\hline $17.00-18.00$ & 1135,00 & 1421,20 & 1761,30 & 1156,50 \\
\hline
\end{tabular}

(Sumber : Analisis, 2019)

\section{Kapasitas (C)}

$\mathrm{C}=\mathrm{Co} \times \mathrm{FCw} \times \mathrm{FCsp} \times \mathrm{FCsf} \quad(\mathrm{smp} / \mathrm{jam})$ dapat dilihat hasil perhitungan pada Tabel 8 .

Tabel 8. Kapasitas Jalan Trans Kalimantan (C)

\begin{tabular}{|c|c|c|c|c|}
\hline Co & FCw & FCsp & Fcsf & \multirow{2}{*}{$\begin{array}{c}\text { Kapasitas Jalan (C) } \\
\text { (smp/jam) }\end{array}$} \\
\hline 2/2D & Lebar Lajur 7 m & Split $(50: 50)$ & $\begin{array}{c}\text { Lebar } \\
\text { Kereb }\end{array}$ & 2759 \\
\hline 3100 & 1,00 & 1,00 & 0,89 & \\
\hline
\end{tabular}




\section{Density (Volume per Capacity) (V/C)}

Tabel 9. Density (V/C) Pos 1 didepan toko buah-buahan dan Tabel 10. Density (V/C) Pos 2 di depan SPBU Handil Bakti yaitu pada Hari Sabtu, Minggu Hari libur dan Senin, Selasa Hari Kerja sebagai berikut :

Tabel 9. Density (V/C) - Pos 1

\begin{tabular}{|c|c|c|c|c|}
\hline \multirow{2}{*}{ Waktu Pengamatan } & \multicolumn{5}{|c|}{ POS 1 } \\
\cline { 2 - 5 } & Sabtu & Minggu & Senin & Selasa \\
\hline $08.00-09.00$ & $\mathrm{C}$ & 0,35 & 0,91 & 0,91 \\
\hline $09.00-10.00$ & 0,66 & 0,43 & 0,95 & 0,59 \\
\hline $10.00-11.00$ & 0,64 & 0,76 & 0,64 & 0,61 \\
\hline $11.00-12.00$ & 0,67 & 0,77 & 0,60 & 0,53 \\
\hline $12.00-13.00$ & 0,63 & 0,80 & 0,56 & 0,46 \\
\hline $13.00-14.00$ & 0,55 & 0,55 & 0,49 & 0,40 \\
\hline $14.00-15.00$ & 0,61 & 0,55 & 0,53 & 0,38 \\
\hline $15.00-16.00$ & 0,61 & 0,49 & 0,49 & 0,47 \\
\hline $16.00-17.00$ & 0,62 & 0,64 & 0,89 & 0,73 \\
\hline $17.00-18.00$ & 0,62 & 0,75 & 1,05 & 1,05 \\
\hline
\end{tabular}

(Sumber: Analisis, 2019)

Density (V/C) yang tertinggi di pos 1 pada hari kerja yaitu pada hari Senin dan Selasa, pada angka 1,05 pada Pukul 17.00-18.00 WITA. Sedangkan dihari libur Density (V/C) yang tertinggi di Hari Minggu adalah 0,80 pada Pukul 12.00-13.00 WITA. Dihari sabtu adalah 0,71 pada pukul 08.00-09.00 WITA.

Tabel 10. Density (V/C) - Pos 2

\begin{tabular}{|c|c|c|c|c|}
\hline \multicolumn{5}{|c|}{ POS 2 } \\
\hline \multirow{2}{*}{ Waktu Pengamatan } & \multicolumn{4}{|c|}{ V/C (LOS) } \\
\cline { 2 - 5 } & Sabtu & Minggu & Senin & Selasa \\
\hline $08.00-09.00$ & 0,61 & 0,24 & 0,33 & 0,91 \\
\hline $09.00-10.00$ & 0,59 & 0,25 & 0,47 & 0,39 \\
\hline $10.00-11.00$ & 0,62 & 0,53 & 0,39 & 0,41 \\
\hline $11.00-12.00$ & 0,56 & 0,50 & 0,44 & 0,45 \\
\hline $12.00-13.00$ & 0,41 & 0,53 & 0,47 & 0,42 \\
\hline $13.00-14.00$ & 0,40 & 0,39 & 0,46 & 0,37 \\
\hline $14.00-15.00$ & 0,34 & 0,39 & 0,51 & 0,36 \\
\hline $15.00-16.00$ & 0,32 & 0,48 & 0,50 & 0,38 \\
\hline $16.00-17.00$ & 0,38 & 0,53 & 0,60 & 0,40 \\
\hline $17.00-18.00$ & 0,41 & 0,52 & 0,64 & 0,42 \\
\hline
\end{tabular}

(Sumber: Analisis, 2019) 
Density (V/C) yang tertinggi di pos 2 pada hari kerja yaitu pada hari Selasa, pada angka 0,91 pada Pukul 08.00-09.00 WITA. Sedangkan dihari libur Density (V/C) berjalan dengan lancar.

\section{Level of Service (LoS) atau Indeks Tingkat Pelayanan (ITP)}

Tabel 11. LoS Pos 1 didepan toko buah-buahan dan Tabel 12. LoS Pos 2 di depan SPBU Handil Bakti yaitu pada Hari Sabtu, Minggu Hari libur dan Senin, Selasa Hari Kerja sebagai berikut :

Tabel 11. Level of Service $(L o S)$ atau Indeks Tingkat Pelayanan (ITP) Pos 1

\begin{tabular}{|c|c|c|c|c|}
\hline \multirow{2}{*}{ Waktu Pengamatan } & \multicolumn{5}{|c|}{ Pevel of Service (Los) atau Indeks Tingkat Pelayanan (ITP) } \\
\cline { 2 - 5 } & Sabtu & Minggu & Senin & Selasa \\
\hline $08.00-09.00$ & C & A & E & E \\
\hline $09.00-10.00$ & B & A & B & B \\
\hline $10.00-11.00$ & B & C & B & A \\
\hline $11.00-12.00$ & B & C & A & A \\
\hline $12.00-13.00$ & B & C & A & A \\
\hline $13.00-14.00$ & A & A & A & A \\
\hline $14.00-15.00$ & B & A & D & C \\
\hline $15.00-16.00$ & B & B & B & F \\
\hline $16.00-17.00$ & B & C & F \\
\hline $17.00-18.00$ & & &
\end{tabular}

ITP F (Arus yang terhambat, kecepatan rendah, volume diatas kapasitas) sering terjadi kemacetan pada waktu yang cukup lama yang tertinggi di pos 1 pada hari kerja yaitu pada hari Senin dan Selasa, pada Pukul 17.00-18.00 WITA. Sedangkan dihari libur ITP D (Arus mulai tidak stabil, kecepatan rendah dan berbeda-beda, volume mendekati kapasitas) di Hari Minggu pada Pukul 12.00-13.00 WITA. Hari Sabtu termasuk ITP D (Arus mulai tidak stabil, kecepatan rendah dan berbeda-beda, volume mendekati kapasitas) pada pukul 08.00-09.00 WITA.

Tabel 12. Level of Service (LoS) atau Indeks Tingkat Pelayanan (ITP) Pos 2

\begin{tabular}{|c|c|c|c|c|}
\hline \multicolumn{5}{|c|}{ POS 2} \\
\hline \multirow{2}{*}{ Waktu Pengamatan } & \multicolumn{5}{|c|}{ Level of Service (Los) atau Indeks Tingkat Pelayanan (ITP) } \\
\cline { 2 - 5 } & Sabtu & Minggu & Senin & Selasa \\
\hline $08.00-09.00$ & $\mathrm{~B}$ & $\mathrm{~A}$ & $\mathrm{~A}$ & $\mathrm{E}$ \\
\hline $09.00-10.00$ & $\mathrm{~A}$ & $\mathrm{~A}$ & $\mathrm{~A}$ & $\mathrm{~A}$ \\
\hline $10.00-11.00$ & $\mathrm{~B}$ & $\mathrm{~A}$ & $\mathrm{~A}$ & $\mathrm{~A}$ \\
\hline $11.00-12.00$ & $\mathrm{~A}$ & $\mathrm{~A}$ & $\mathrm{~A}$ & $\mathrm{~A}$ \\
\hline $12.00-13.00$ & $\mathrm{~A}$ & $\mathrm{~A}$ & $\mathrm{~A}$ & $\mathrm{~A}$ \\
\hline
\end{tabular}


JURNAL KACAPURI

JURNAL KEILMUAN TEKNIK SIPIL

Volume 2 Nomor 2 Edisi Desember 2019

\begin{tabular}{|c|c|c|c|c|}
\hline $13.00-14.00$ & $\mathrm{~A}$ & $\mathrm{~A}$ & $\mathrm{~A}$ & $\mathrm{~A}$ \\
\hline $14.00-15.00$ & $\mathrm{~A}$ & $\mathrm{~A}$ & $\mathrm{~A}$ & $\mathrm{~A}$ \\
\hline $15.00-16.00$ & $\mathrm{~A}$ & $\mathrm{~A}$ & $\mathrm{~A}$ & $\mathrm{~A}$ \\
\hline $16.00-17.00$ & $\mathrm{~A}$ & $\mathrm{~A}$ & $\mathrm{~A}$ & $\mathrm{~A}$ \\
\hline $17.00-18.00$ & $\mathrm{~A}$ & $\mathrm{~A}$ & $\mathrm{~B}$ & $\mathrm{~A}$ \\
\hline
\end{tabular}

ITP E (Arus tidak stabil, kecepatan rendah dan berbeda-beda, volume mendekati kapasitas) yang tertinggi di Pos 2 pada hari kerja yaitu hari Selasa, Pukul 08.0009.00 WITA. Sedangkan dihari libur ITP A (Arus bebas, volume rendah dan kecepatan tinggi) berjalan dengan lancar.

\section{PENUTUP}

\section{Kesimpulan}

Dari hasil penelitian dan analisa data terhadap kinerja Jalan Trans Kalimantan Handil Bakti (KM. $1+000$ s.d KM. $2+900$ ) Kabupaten Barito Kuala yang dilokasikan pada 2 (dua) Pos yaitu Pos 1 di depan Toko Buah-Buahan dan Pos 2 di depan SPBU Handil Bakti yang dilaksanakan penelitian selama 4 hari yaitu pada sabtu, minggu, senin, selasa maka dapat diambil kesimpulan sebagai berikut:

1. Volume Lalu lintas di pos 1 tertinggi selama 4 hari penelitian yaitu pada hari senin 6272 kendaraan $(2883,50 \mathrm{smp} / \mathrm{jam})$ dan selasa 6275 kendaraan (2887,40 smp/jam) pada jam 17.00-18.00 WITA. Sedangkan di pos 2 yang tertinggi adalah pada hari selasa pada jam 08.00-09.00 WITA sebanyak 5158 kendaraan $(2517,10 \mathrm{smp} / \mathrm{jam})$.

2. Kapasitas Jalan Trans Kalimantan sebesar 2759 smp/jam (perhitungan MKJI 1997) dengan pembagian dua arah tanpa media, luar kota, dengan lebar efektif 7 meter.

3. Ditinjau dari tingkat pelayanan eksisting di Jalan Trans Kalimantan yang paling tertinggi didapat pada hari Senin dan Selasa di jam sore menjelang malam yaitu jam 17.00-18.00 WITA dengan rasio densitas $(\mathrm{V} / \mathrm{C})=1,05$ dan ITP F (Arus yang dipaksakan atau macet, kecepatan rendah, volume dibawah kapasitas, antrian panjang dan terjadi hambatan-hambatan yang besar).

\section{Saran-saran}

Beberapa saran yang dapat penulis berikan, sebagai berikut :

1. Penelitian ini hanya dilakukan pada ruas Jalan Trans Kalimantan dan dilaksanakan pada dua Pos yaitu Pos 1 bertempat didepan Toko Buah-Buahan sedangkan Pos 2 didepan SPBU Handil Bakti. karena tidak keseluruhan ruas jalan yang diambil maka perlu kajian yang lebih komprehensif bahwa ruas tersebut dapat mewakili keseluruhan sehingga karakteristik lalu lintas yang didapat bisa diaplikasikan kesemua ruas jalan.

2. Diharapkan kepada Instansi terkait (Pemerintah Daerah Kabupaten Barito Kuala) untuk mengambil tindakan yaitu pengalihan lahan pedagang kaki lima agar bisa melakukan pelebaran jalan agar tidak terjadi penumpukan kendaraan 
pada jam jam tertentu pada Jalan Trans Kalimantan yaitu pada Pos 1 didepan Toko Buah-Buahan.

3. Perlu dikembangkan jenis tiap segmen hubungan antara karakteristik lalu lintas dengan jenis kendaraan seperti MC, LV, HV.

\section{Ucapan Terimakasih}

Penulis mengucapkan terimakasih kepada kawan-kawan dan rekan sejawat di Program Studi (S-1) Teknik Sipil, Fakultas Teknik, Universitas Islam Kalimantan Muhammad Arsyad Al Banjari serta semua pihak yang telah banyak membantu kelancaran dan selesainya penelitian ini.

\section{DAFTAR PUSTAKA}

Anonim (1994), Highway Capacity Manual, Washington DC: Transportation Research Board, National Research Council

Anonim (2006), Peraturan Menteri Perhubungan Nomor KM 14 Tahun 2006 tentang Manajemen dan Rekayasa Lalu lintas di Jalan, Jakarta: Menteri Perhubungan RI

Anonim (2006), Peraturan Pemerintah Republik Indonesia Nomor 34 Tahun 2006 tentang Jalan. Jakarta: Pemerintah Indonesia.

Direktorat Jenderal Bina Marga Direktorat Bina Jalan Kota (BINKOT) (1997), Manual Kapasitas Jalan Indonesia 1997. Direktorat Jenderal Bina Marga Direktorat Bina Jalan Kota (BINKOT).

Direktorat Pembangunan Jalan Perkotaan (1997), Manual Kapasitas Jalan Indonesia (MKJI) 1997, Direktorat Jendral Bina Marga, Jakarta.

Kementerian Pekerjaan Umum Direktorat Jenderal Bina Marga. 2013. Manual Desain Perkerasan Jalan. Kementerian Pekerjaan Umum Direktorat Jenderal Bina Marga.

Munawar, A, (2006), Manajemen Lalu Lintas Perkotaan, Yogyakarta: Beta Offset

Morlok, E. (1995), Pengantar Teknik dan Perencanaan Transportasi. Jakarta.

Oglesby, E.K, dan Hicks, R.G. (1988), Teknik Jalan Raya, Jakarta: Penerbit Erlangga.

Sukirman, Silvia. (1999), Dasar-Dasar Perencanaan Geometrik Jalan. Bandung: Nova.

Said, Adhi Surya (2019), Analisis Kapasitas dan Tingkat Pelayanan ruas Jalan Brigjen H. Hasan Basry Kota Banjarmasin, Prosding Pekan Ilmiah Uniska MAB ke-38 Tahun, Banjarmasin.

Tamin, O.Z. (1997), Perencanaan dan Permodelan Transportasi. Bandung: Penerbit Tarsito.

Tamin, Ofyar Z. (2000), Perencanaan dan Pemodelan Transportasi. Bandung: Institut Teknologi Bandung.

Wells. G. R. (1993), Rekayasa Lalu Lintas. Jakarta: Penerbit Bharatara. 